\title{
An examination of Article 27 of the TRIPS Agreement in relation to the provisions on patentable subject matter under the PDA in Nigeria
}

\author{
Temitope O. Oloko* \\ The Centre for Intellectual Property Law, University of Pretoria, Pretoria, South Africa \\ *Email: temitope.yerokun-oloko@lasu.edu.ng
}

Article 27 of the TRIPS Agreement remains the most controversial provision of the TRIPS Agreement. This provision on patentable subject matter stipu-lates what is permissible under patent law. This article evaluates the Patent and Designs Act by considering the extent of compliance of the Act as pro-vided by the TRIPS Agreement. To this end, the paper proceeds in four parts excluding the introduction. In the first section, it situates the discussion within the general framework of Patent and Designs Act. The next section, turns to an examination of the compliancy of the law. Finally, in the fourth and fifth sections, it analyses the modifications necessary against the back-drop of the examination carried out in the previous section. In the concluding section, a summary of the compliance of the law in relation to the TRIPS Agreement is provided.

\section{Introduction}

Patents today are associated with economic, health, cultural and social conditions prevailing in any country. There is no doubt that patents have assisted in development and have created a lot of benefits. Inventions have been an important part of human development and have made life much easier. ${ }^{1}$

Patents have been the most controversial aspect of intellectual property since the Agreement on Trade Related Aspect of Intellectual Property (TRIPS Agreement) came into being, particularly with regards to what are patentable subject matters and uses without authorisation of the right holder, especially, with reference to public health.

The purpose of this article is to explore the conformity of the patentable subject matter in the Patent and Design Act $^{2}$ (PDA) with Article 27 of the TRIPS Agreement.

This chapter will examine the patent law, beginning with an overview of the current status of the legal framework. An examination to determine its compliancy and the interpretation thereof will then be carried out. By implication, the

\footnotetext{
${ }^{1}$ Such inventions include electricity, telephones, cars, airplanes, ships, refrigeration, television and medicines which are essential to life.

${ }^{2}$ Cap P2 (Vol 13) Laws of Federation of Nigeria 2004. (Herein after 'the PDA' or the
'Act.).
} 
legal framework in this context will be viewed against the provisions of the TRIPS Agreement.

\section{Patent laws in Nigeria}

\section{Historical development of patents in Nigeria}

The historical development of the Nigerian patent system can be traced back to the Paris Patent Conference of 1879, where the decision to extend patent laws and systems to colonial territories was initiated. ${ }^{3}$ The first Nigerian patent legislations were enacted in 1900. These were the Patents Ordinance No 17 of $1900^{4}$ and the Patents Proclamation Ordinance No 27 of $1900^{5}$ applicable to the colony of Lagos and Southern Nigeria respectively. A similar provision was later applied to Northern Nigeria by virtue of the Patents Proclamation Ordinance No 12 of 1902. ${ }^{6}$ These ordinances provided for an independent patenting system in the various parts of the country. ${ }^{7}$

Following the amalgamation of Northern and Southern Nigeria in 1914, the Patent Ordinance and Patent Proclamation Ordinances were repealed and replaced with the Patents Ordinance No 30 of $1916^{8}$ which abolished the independent patenting system under the previous Ordinances. It was renamed and re-enacted in 1925 as the Registration of United Kingdom Patents Ordinance of $1925 .^{9}$ Under the 1925 Ordinance, patents could be granted only in the United Kingdom, however, they would be valid in Nigeria if an application is registered within three years of the grant of the patent in the United Kingdom. ${ }^{10}$

After independence in 1960, the Registration of United Kingdom Patents Act ${ }^{11}$ Ordinance of 1925, the Patents Rights (Limitation) Act $1968^{12}$ and Patents

\footnotetext{
${ }^{3}$ Edith Penrose, The Economics of International Patent System (John Hopkins Press, Baltimore 1951) 53 .

${ }^{4}$ Ordinances of the Colony of Lagos, 892 (1901).

${ }^{5}$ Laws of the Protectorate of Southern Nigeria Ch 48, 653 (1908).

${ }^{6}$ Laws of the Protectorate of Northern Nigeria 415 (1910).

${ }^{7}$ Charles Mwalimu, Nigeria Legal System Private Law (Vol 2 Peter Lang, New York 2009) 518-19. The independent patenting system has been regarded as an anomaly and ambitious within the period of its occurrence considering the standard of western civilization and level of western technological know-how available in the indigenous population at the time. See Patents - The Requirement for Patentability in Nigeria, p 2 available as $<$ http://www.allanogunkeye.com/allan/RequiREMENT15.pdf $>$ accessed 15 June 2015.

${ }^{8}$ Nigerian Ordinance 401 (1916) Cap 141 Laws of Nigeria.

${ }^{9}$ Registration of United Kingdom Patents Ordinance No 6 of 1925, Cap 182 Laws of the Federation of Nigeria and Lagos 1958.

${ }^{10}$ An Overview of the Law of Patents in Nigeria, p $2<\mathrm{http}: / / w w w . n i g e r i a n l a w g u r u . c o m / a r$ ticles/intellectual\%20property\%20law/AN\%20OVERVIEW\%20OF\%20THE\%20LAW\% 20OF\%20PATENTS\%20IN\%20NIGERIA.pdf> accessed 15 July 2015.

${ }^{11}$ Ordinance No 6 of 1925.

${ }^{12}$ This law was enacted in 1968 to enable the government of Nigeria and third parties use certain inventions. Mwalimu (n 7) 519.
} 
Act 1949 of the United Kingdom and amendments thereof remained in force in Nigeria until 1970. Subsequently, all these laws were repealed by the Patents and Designs Act No 60 of $1970 .{ }^{13}$ Notably, this means that there was no Nigerian legislation empowered to grant patents from 1924 to $1970 .{ }^{14}$ In 1970 when the patent law was first reviewed after independence, apart from the fact that there was no tangible reason behind the enactment of Patents and Designs Act beyond nationalising the patent application and the grant process, there appeared to be no policy rationale or consideration as such behind adopting the Model Law for developing countries created by United International Bureau for the Protection of Intellectual Property (BIRPI). ${ }^{15}$ There was no national policy with regard to industrial and technological development and the PDA was simply fashioned after the Model Law for developing countries. As Adewopo confirms, it was not based on any defined or underlying policy consideration. ${ }^{16}$ The Patents and Designs Act of $1970^{17}$ remains the substantive law on Patents and Designs without any subsequent amendments. The Patent and Designs Act of 1970 is in chapter 2 of the 2004 Laws of the Federation of Nigeria. ${ }^{18}$

\section{Overview of the patent law}

\section{Conferment of patent}

Patent rights are protected under the Patent and Designs Act of $1970 .{ }^{19}$ The conferment of a patent is effected by section 2 of the PDA. The right to a patent is vested in the statutory inventor: this is the person who, whether or not he is the true inventor, is the first to file or validly claim a foreign priority for a patent application in respect of an invention. ${ }^{20}$ The true inventor, whether or not he is also the statutory inventor, is entitled to be named in the patent as such, and the entitlement in question shall not be modifiable by contract. ${ }^{21}$ The law regards the statutory inventor as the applicant that is, the person who files the application for

\footnotetext{
${ }^{13}$ PDA 1970 P2 LFN 2004, s 31(1); Sikoyo et al., Intellectual Property Protection in Africa Status of Laws, Research and Policy Analysis in Ghana, Kenya, Nigeria, South Africa and Uganda African Centre for Technology Studies (ACTS) Ecopolicy Series no 16, p 18 see also See Patents - The Requirement for Patentability in Nigeria available at $<$ http://www.allanogunkeye.com/allan/RequiREMENT15.pdf $>$ accessed 15 June 2015; FO Babafemi, Intellectual Property The Law and Practice of Copyright Trade Marks, Patent and Industrial Design in Nigeria (Justinian Ibadan 2007) 89.

${ }^{14}$ Mwalimu (n 7) 519; J Ola Orojo, Nigerian Commercial Law and Practice (Sweet \& Maxwell 1983) 1106.

${ }^{15}$ World Intellectual Property Organisation's predecessor.

${ }^{16}$ Adebambo Adewopo, 'Public Health, Access to Medicines and the Role of Patents System in Nigeria' (2011) NIALS Journal of Intellectual Property Maiden Edition 171, 164-90.

${ }^{17}$ PDA 1970 P2 LFN 2004.

${ }^{18}$ Ibid.

${ }^{19}$ Ibid.

${ }^{20}$ PDA 1970 P2 LFN 2004, s 2(1).

${ }^{21}$ PDA 1970 P2 LFN 2004, s 2(2).
} 
patent, whereas the true inventor is the person who invented the product or process, that is, the person who conceives the subject matter in question, as opposed to someone who only contributes suggestions about the invention before or after conception. $^{22}$

This depiction makes it impossible for companies sponsoring research and innovation to be named as inventors, as the law does not allow this provision to be modified by contracts. ${ }^{23}$ On the other hand, the right to a patented invention created in the course of employment is vested in the employer, ${ }^{24}$ likewise inventions that result from the execution of a contract for the performance of a specified work vest in the person who commissions the work. $^{25}$

The patent rights of employee and employer are not balanced in the PDA as it creates a blanket provision. For instance, if an employee's contract does not require inventive activity but he uses his employer's data or means at his disposal, the invention will be regarded as the employer's. ${ }^{26}$ Does the employer still have a patent right if the invention does not relate in any form to the employer's works? In subsection (ii), ${ }^{27}$ if the invention is of exceptional importance, the inventor will be given a fair remuneration which will depend on his salary and the importance of the invention. ${ }^{28}$ Again the employer takes all, as this provision cannot be modified by contract. $^{29}$ Although the provision gives some form of remuneration to the employee, what is 'exceptional importance' may be relative and may not be determinable immediately $^{30}$ which gives the employer room to manoeuvre. It is submitted that, since the intent of patent law is to reward the inventor for his efforts, patent rights should vest in the employee even though he used the resources of the employer. Adequate compensation should be given to the employer whose resources were used and not the other way round. Clearly, these issues come up due the fact that PDA is over forty years old. In other jurisdictions these issues have been corrected in most legislation and case law relating to such issues is well-defined.

\footnotetext{
${ }^{22}$ Mark J Davision, Ann L Monotti and Leanne Wiseman, Australian Intellectual Property Law (Cambridge University Press 2008) 482.

${ }^{23}$ PDA 1970 P2 LFN 2004, s 2(2).

${ }^{24}$ This follows the Common Law position where inventions created in the course of employment belongs to the employer. See Patchet $v$ Sterling [1955] AC 534.

${ }^{25}$ PDA 1970 P2 LFN 2004, s 2(4).

${ }^{26}$ PDA 1970 P2 LFN 2004, s 2(4) (a) (i).

${ }^{27}$ PDA 1970 P2 LFN 2004, s 2(4) (a) (ii).

${ }^{28}$ Ibid.

${ }^{29}$ PDA 1970 P2 LFN 2004, s 2(4) (b).

${ }^{30} \mathrm{An}$ invention may not worth anything at the time of invention but may after a few years become a money spinning invention; if the invention was not of any exceptional importance at the time of invention the employee gets nothing even where the invention had nothing to do with the employers business.
} 
Requirements for patentability

The PDA in section 1 provides that a patent may be granted for an invention if it is new, ${ }^{31}$ results from inventive activity ${ }^{32}$ and is capable of industrial application. ${ }^{33}$ In addition, inventions that result from an improvement upon a patented invention which is new, result from inventive activity and are capable of industrial application are patentable. ${ }^{34}$ This provision is one of the hallmarks of the PDA as it is capable of stimulating indigenous invention, ${ }^{35}$ although it has been underutilised. Remarkably, nowhere in the PDA are inventions defined, so what constitutes an invention is not known or may be subject to known definitions. Inventions and patentability are two distinctly separate concepts ${ }^{36}$ which have been merged together under the PDA. The PDA does not specifically provide that products and processes are patentable, however, section 3 provides that applications may include claims for products and manufacturing processes. ${ }^{37}$

\section{Excluded subject matter}

Under the PDA a number of exceptions to a patentable subject matter are mentioned. Plant or animal varieties, or essentially biological processes for the production of plants or animals are expressly excluded from patent protection, with the exception of microbiological processes and their products. ${ }^{38}$ In addition, inventions contrary to public order or morality are not patentable whether they are prohibited by law or not. ${ }^{39}$ Also, principles and discoveries of a scientific nature are not regarded as inventions under the PDA. ${ }^{40}$

\section{Obtaining a patent}

The procedure for granting a patent in Nigeria includes certain formalities which must be complied with. Patent applications require specific features for the

\footnotetext{
${ }^{31}$ 'New' according to the PDA mean an invention is new if it does not form part of the state of the art. ('the state of the art' means everything concerning that art or field of knowledge which has been made available to the public anywhere and at any time whatever by means of a written or oral description, by use or in any other way before the date of the filing of the patent application relating to the invention or the foreign priority date validly claimed in respect thereof ) See PDA 1970 P2 LFN 2004, s 1(2) (a).

${ }^{32}$ Inventive activity according to the PDA must be an invention that results from inventive activity if it does not obviously follow from the state of the art, either as to the method, the application, the combination of methods, or the product which it concerns, or as to the industrial result it produces. See PDA 1970 P2 LFN 2004, s 1(2) (b).

${ }^{33}$ PDA 1970 P2 LFN 2004, s 1(1) (a).

${ }^{34}$ PDA 1970 P2 LFN 2004, s 1(1) (b).

${ }^{35} \mathrm{AO}$ Oyewunmi, 'Industrial Property Law' in EO Akanki (ed), Commercial Law in Nigeria (University of Lagos Press 2005) 45.

${ }^{36}$ Novartis AG v Union of India (UOI) and Ors; Natco Pharma Ltd $v$ UoI \& Ors; M/S Cancer Patients Aid Association v UoI \& Ors. Citations: Civil Appeal No 2706-2716 of

2013 para 9.

${ }^{37}$ PDA 1970 P2 LFN 2004, s 3(3) (a) \& (b).

${ }^{38}$ PDA 1970 P2 LFN 2004, s 1(4) (a).

${ }^{39}$ PDA 1970 P2 LFN 2004, s 1(4) (b).

${ }^{40}$ PDA 1970 P2 LFN 2004, s 1(5).
} 
application to be processed. All patent applications are to be made to the Registrar, Patents Branch of the Trademarks, Patent and Design Registry. ${ }^{41}$

The patent application shall contain only one invention but may include claims for any number of products, manufacturing processes for those products, and applications of those products. ${ }^{42}$ In addition, claims for any number of processes, means of working those processes, the resulting product or products, the application of those products have to be taken into account when considering the patent application for the invention. ${ }^{43}$ Also, a declaration by the true inventor is signed requesting that he be mentioned in the patent where appropriate. ${ }^{44}$

All patent applications are examined by the registrar as to conformity with section 3 (1), (3) and (4) of the PDA. ${ }^{45}$ Only non-compliance with section 3 (1) brings about an outright rejection of the application, ${ }^{46}$ other requirements may be addressed by inviting and notifying the applicant to make appropriate corrections, failing which the application will be rejected. ${ }^{47} \mathrm{~A}$ claim as to a priority date in respect of an earlier application made in a country outside Nigeria may be possible only if made not more than three months after the making of the application, ${ }^{48}$ if this has not been complied with, it will be disregard. Unfortunately, where all the requirements have been met the patent is granted without further examination as to whether it is patentable, the description and claims meet the definition according to section 3(2) or if there has been a prior application benefiting from foreign priority made in Nigeria in respect of the same invention and whether the patent has been granted as a result of such an application. $^{49}$ In essence, there is no substantive examination of patent applications; administrative requirements alone are required to be met for patents to be granted. ${ }^{50}$ This method of examination is not limited to Nigeria. Other countries, such as South Africa, have examination of patent application as a formality as well. $^{51}$ Patents in Nigeria are granted at the risk of the patentee and without guarantee of their validity. ${ }^{52}$ The system is set up merely to give the applicant a

\footnotetext{
${ }^{41}$ Commercial Law Department, Federal Ministry of Trade and Investment in Nigeria Federal Capital Territory, Abuja.

${ }^{42}$ PDA 1970 P2 LFN 2004, s 3 (3) (a).

${ }^{43}$ PDA 1970 P2 LFN 2004, s 3 (3) (b).

${ }^{44}$ PDA 1970 P2 LFN 2004, s 3 (1) (b) (ii).

${ }^{45}$ Patent Rules L.N. 96 of 1971, r 11 (e).

${ }^{46}$ PDA 1970 P2 LFN 2004, s 4 (1) (a).

${ }^{47}$ PDA 1970 P2 LFN 2004, s 4 (1) (b).

${ }^{48}$ PDA 1970 P2 LFN 2004, s 3 (4) (b).

${ }^{49}$ Ibid.

${ }^{50}$ See generally Ikechi Mgbeoji, 'African Patent Offices Not fit for Purpose', in Jeremy de Beer, Chris Armstrong, Chidi Oguamanam and Tobias Schonwetter Innovation and Intellectual Property collaborative Dynamics in Africa (University of Cape Town Press, Claremont 2014) 234.

${ }^{51}$ However, there is a major difference in the provisions of the South African Patent Act and the Nigerian Patent Act, in that the South African Patent Act categorically states that the specification of the application must comply with the requirements of this Act. See section 34 South African Patent Act 57 of 1978 compare with PDA 1970 P2 LFN 2004, s 4 (1) (a).

${ }^{52}$ PDA 1970 P2 LFN 2004, s 4 (4).
} 
letter and record his name in a register. A lack of expertise and facilities has been put forward as reasons for the present state of affairs. ${ }^{53}$ However, these explanations may not be totally correct as examination of the applications can be carried out by outsourcing on behalf of the country. ${ }^{54}$ It may be that the lack of an inventive culture has kept the law where it is for so long: if there were a community of inventors in Nigeria there would have been an outcry to reform the law. ${ }^{55}$ The few inventors prefer to have their inventions patented in the US or elsewhere. Inadequate infrastructure to enable research and development has resulted in a very low turnout of inventions and even improvements on inventions.

The right conferred on the patentee is a right to prevent other persons from making, importing, selling or using a product, or stocking it for the purpose of sale or use where the grant is for a product patents. However, rights in relation to a process patent include any act of applying the process or doing, in respect of a product obtained directly by means of the process as well as making, importing, selling or using the product, or stocking it for the purpose of sale or use. $^{56}$

What is protected by the patent is limited to the terms of the claims and the description included in the patent which shall be used to interpret the claims. ${ }^{57}$ The scope of protection covers only what has been claimed in the patent application and cannot be extended to claims that are not in the application. ${ }^{58}$ The PDA, however, provides in section 6 (3) that the rights granted by a patent extends only to acts done for industrial or commercial purposes ${ }^{59}$ and such rights shall not include acts done on a product covered by the patent after the product has been lawfully sold in Nigeria except the if patentee has made special application for the product, in which case it would be reserved. ${ }^{60}$

As noted above, the PDA grants patent rights based on a foreign priority. Section 6 (4) on the issue is curiously worded and provides thus

Where, at the date of the filing of a patent application in respect of a product or process or at the date of a foreign priority validly claimed in respect of the application, a person other than the applicant-

(a) was conducting an undertaking in Nigeria; and

(b) in good faith and for the purposes of the undertaking, was manufacturing the product or applying the process or had made serious preparations with a view to doing so, then, notwithstanding the grant of a patent, there shall exist a right (exercisable by

\footnotetext{
${ }^{53}$ Folarin Shyllon, Intellectual Property Law in Nigeria (Max Planck Institute for Intellectual Property, Competition and Tax Law, Munich 2003) 147.

${ }_{55}^{54}$ Singapore and United Arab Emirate outsource patent search and examination.

${ }^{55}$ The outcry for better copyright protection in the late 1980s was as a result of performing artists needing better protection for their works this has not been the case for inventors.

${ }^{56}$ PDA 1970 P2 LFN 2004, s 6 (1).

${ }^{57}$ PDA 1970 P2 LFN 2004, s 6 (2).

${ }^{58}$ Ibid.

${ }^{59}$ PDA 1970 P2 LFN 2004, s 6 (3) (a).

${ }^{60}$ PDA 1970 P2 LFN 2004, s 6 (3) (b).
} 
the person for the time being conducting the undertaking, and not otherwise) to continue the manufacture or application, or to continue and complete the preparations and thereafter undertake the manufacture or application, as the case may be, and in respect of any resulting products to do any other act mentioned in subsection (1) of this section.

The section 6 (4) provision is overreaching in its intent to protect indigenous inventions against competing foreign inventions. At the time the PDA was enacted, Nigeria, as a new nation, was eager to protect its own people who had to compete with foreigners who had better infrastructure and technical knowhow. This provision was necessary in the 1970 s to encourage Nigerian inventors once they have made serious preparations. However, it seems to have had the effect of discouraging foreign patent applications and investment in technology and has been made worse by the Nigerian Enterprises Promotion Act. ${ }^{61}$

The provision has been questioned as it conflicts with other provisions ${ }^{62}$ of the PDA in that it negates the provision on newness and obviousness. ${ }^{63}$ Once a product is manufactured it can no longer be regarded as new, therefore no patent should be granted. However, if serious preparations are still being made for such as experimental use, then this provision may apply to the benefit of the Nigerian inventor where the foreign inventor claims a foreign priority date. It seems that the first inventor would not be impeded by this provision as the PDA grants patents to the first to file, but there would be a concurrent user with the same rights conferred as on the patentee.

With regards to international obligations, as in the case of trade marks, a ministerial declaration by an order in the Federal Gazette has to be made for treaty, convention and international obligations to be enforceable in Nigeria. ${ }^{64}$ The declaration is to contain the countries with which Nigeria has treaty obligations. Without such an order a foreign priority cannot be claimed. Strangely, unlike for trademarks, a ministerial declaration was passed in 1971 in which the Paris Convention was listed. ${ }^{65}$ Notably, the declaration came into force at the same time the PDA and the Patent Rules came into force ${ }^{66}$ However, there has been no update of the declaration.

\section{Term of protection of patent}

As in many other countries, ${ }^{67}$ the PDA provides a 20 -year term of protection from the date of the filing of the patent application. ${ }^{68}$ Patents are required to be

\footnotetext{
${ }^{61}$ Nigerian Enterprises Promotion Act No 4 of 1972.

${ }^{62}$ PDA 1970 P2 LFN 2004, s 1 (1) and s 9 especially subsection 9 (1) (2) (c); Patent Rules L.N. 96 of $1971 \mathrm{r}$ 17. See also Janssen Pharmaceutical M.V. v Registrar of Patent and Designs (1991) 3 NWLR 116.

${ }^{63}$ Oyewunmi (n 38) 467-68.

${ }^{64}$ PDA 1970 P2 LFN 2004, s 27 (1).

${ }^{65}$ Patents and Designs (Convention Countries) Order of 1971.

${ }^{66} 1$ December 1971.

${ }^{67}$ Germany, Switzerland, United Kingdom and United States.

${ }^{68}$ PDA 1970 P2 LFN 2004, s 7 (1) and Patent Rules L.N. 96 of 1971 r 18.
} 
renewed annually failing which they lapse. However, a grace period of six months is set to allow payment of such fees with a surcharge for late payment. ${ }^{69}$ The issue of payment of an annual fee will be entertained only after the grant of the patent, as stated in Pfizer Inc $v$ Ployking Pharmaceutical Ltd \& Another. ${ }^{70}$ Also, when the patent expires or lapse, notice shall be given of such and that shall be registered. ${ }^{71}$

\section{Patents: compliancy}

This section looks at the Patent and Design Act and the TRIPS Agreement in relation to international practices and obligations to determine if the PDA is in compliance with the TRIPS Agreement. Suggestions for modification of the Act that would project the national and public interest as well as encourage inventions will be given in later sections of this chapter.

As stated in previous chapters, the TRIPS Agreement adopted the various intellectual property conventions, including the Paris Convention which comprises provisions on patent protection. Prior to comparing the scope of protection under the Patent and Design Act and the TRIPS Agreement, it is advantageous to examine the Paris Convention to provide a thorough assessment of the impact of the TRIPS Agreement. An examination of the relationship between the Paris Convention and the TRIPS Agreement will highlight provisions that relate to patents which may come up in later discussions in the chapter.

\section{Relationship of the TRIPS Agreement to the Paris Convention and patent protection}

Article 2.1 of the TRIPS Agreement states that members shall comply with Articles 1 through 12 and article 19 of the Paris Convention. The particular articles that relate to patent are articles 4 to 5quater. Unlike the provisions on copyrights and trademarks, which are very similar to what is in the Convention, the provision on patents created new provisions that were not specifically provided for in the Paris Convention and were left for countries to decide how they are to be protected. As noted in chapter 5 these provisions were carefully selected as they are the material provision in relation to patent protection in the Paris Convention.

As expected, members are required to treat foreign nationals in the same way they treat their own nationals with regard to intellectual property protected under the Paris Convention. The protection of patents was at the forefront of intellectual property issues during the Uruguay Round, which was central to the objective of moving intellectual property matters form WIPO to WTO.

\section{Article 27: patentable subject matter}

Patentable subject matter consists of the subject matter which is permissible under the patent law as protectable. Conflict and uncertainty surround the issue

\footnotetext{
${ }^{69}$ PDA 1970 P2 LFN 2004, s 7 (2).

${ }^{70}(1997-2003) 4$ I.P.L.R 2151998 F.H.C. 1.1.

${ }^{71}$ PDA 1970 P2 LFN 2004, s 7 (3).
} 
of what ought to be patented or not. ${ }^{72}$ There are certain conditions that have to be fulfilled for an invention to be patentable. As stated earlier pursuant to the PDA, an invention is patentable if it is new, results from inventive activity and is capable of industrial application, or if it constitutes an improvement upon a patented invention and also is new, results from inventive activity and is capable of industrial application. ${ }^{73}$ The requirement for patent protection is similar to article 27.1 of the TRIPS Agreement. However, the PDA does not expressly mention products and processes in section 1 on patentable inventions: the PDA merely refers to products and processes in relation to patent applications. ${ }^{74}$ The exclusion of product patents from protection is a source of concern for industrialised countries and they have continuously pushed for the protection of all products and process that meet the requirement for patenting. ${ }^{75}$ The protection of product patent that particularly relates to pharmaceutical products could not be patented in many countries ${ }^{76}$ till the second half of the last century. ${ }^{77}$ However, the PDA does not limit patents to particular fields of technology: in essence all fields of technology can be patented under the PDA except for specific exemptions.

Pharmaceutical patents, or the patenting of medicine, have been a controversial issue under the TRIPS Agreement. Patented medicines are a multi-billion dollar industry highly protected by industrialised counties. Over the years there have been many arguments for and against the protection of medicines. Rights holders, such as pharmaceutical companies, claim to have invested resource on research and development and, therefore, need to recoup such investments ${ }^{78}$; consumers claim such patents are detrimental to their right to health and allege that patents kill. ${ }^{79}$ Product patents may be allowed, but it should be borne in mind that drugs are manufactured to save lives or to assist in prolonging life or to cure a particular disease.

\footnotetext{
${ }^{72}$ Bently and Sherman, Intellectual Property Law (Oxford University Press, UK 2002) 362.

${ }^{73}$ PDA 1970 P2 LFN 2004, s 1 (1) (a) and (b).

${ }^{74}$ PDA 1970 P2 LFN 2004, s 3 (3) (a) and (b).

${ }^{75}$ Julio Nogués, 'Patents and Pharmaceutical Drugs: Understanding the Pressures on Developing Countries' (1990) 24 Journal of World Trade, no 6, 81-104, 83.

${ }^{76}$ Germany France Italy Japan Sweden Switzerland.

${ }^{77}$ Michele Boldrin and David Levine against Intellectual Monopoly (Cambridge University, Press New York 2008) ch 9, p 3-5 <http://levine.sscnet.ucla.edu/papers/ip.ch.9. m1004.pdf $>$ accessed 30 September 2014.

${ }^{78}$ Chandra Nath Saha and Sanjib Bhattacharya, 'Intellectual Property Rights: An Overview and Implications in Pharmaceutical Industry', (2011) Apr-Jun; 2(2) Journal of Advance Pharmaceutical Technology \& Research 88-93, 90.

${ }^{79}$ See Ruth Mayne, 'The Global Campaign on Patents and Access to Medicines: An Oxfam Perspective', in Peter Drahos and Ruth Mayne (eds), Global Intellectual Property Rights: Knowledge Access and Development (MacMillan Press, UK 2002), Chp 15. Me' decins Sans Frontie'res (2003) 'Trading Health Away: Intellectual Property and Access to Medicines in the Free Trade Area of the America's (FTAA) Agreement', New York, September, <http://www.doctorswithoutborders.org/publications/reports/2003/FTAA_Advo cacy.pdf $>$ accessed 30 September 2015.
} 
A major problem that arises out of product patent protection is the prevention of competition by generic products: brand-name companies refuse to grant licenses and attempt to extend the life of the patent. ${ }^{80}$ The process of extending the life of patents is known as the evergreen patent system or 'ever greening', which is a strategy used to apply for 'secondary patents over related or derivative technologies'. ${ }^{81}$ The strategy has been the subject of litigation in developing countries. A recent case in India is Novartis $A G v$ Union of India (UOI) ${ }^{82}$ where Novartis sought to patent an updated version of an existing cancer drug called Imatinib, a therapeutic drug for chronic myeloid leukemia and certain kinds of tumours, marketed under the names 'Glivec' or 'Gleevec'. As explained by the court in Novartis $A G$ :

Jürg Zimmermann [working for Novartis], invented a number of derivatives of N-phenyl-2- pyrimidine amine, one of which is CGP 571481 in a free base form (later given the International Nonproprietary Name 'Imatinib' by the World Health Organisation). These derivatives, including Imatinib2, are capable of inhibiting certain protein kinases, especially protein kinase C and PDGF (platelet-derived growth factor)-receptor tyrosine kinase and have valuable anti-tumour properties. They can be used in the preparation of pharmaceutical compositions for the treatment of warm-blooded animals, for example, as anti-tumoral drugs and as drugs against atherosclerosis. The N-phenyl-2-pyrimidine-amine derivatives, including Imatinib, were submitted for patent in the US.

The application was made on April 28, 1994 and a patent was granted on May 28, 1996 under US Patent No 5,521,184 (hereinafter referred to as 'the Zimmermann Patent'). The Zimmermann compounds (i.e., derivatives of N-phenyl-2-pyrimidineamine) were also granted a European patent under Patent No EP-A-0 $564409 .^{83}$

The appellant filed the application (Application No 1602/MAS/1998)1 for a grant of patent for Imatinib Mesylate in beta crystalline form at the Chennai Patent Office in India on 17 July 1998. In the application, it was claimed that the invented product, the beta crystal form of Imatinib Mesylate, had (i) more beneficial flow properties; (ii) better thermodynamic stability; and (iii) lower hygroscopicity than the alpha crystal form of Imatinib Mesylate. It was argued that hese properties made the invented product 'new' as it 'stores better and is easier

\footnotetext{
${ }^{80}$ Robert Weissman, 'Victory and Betrayal: The Evergreen Patent System of Pharmaceutical Company Tactics to Extend Patent Protections' Multinational Monitor (Jun 2002, vol 23 no 6) <http://www.multinationalmonitor.org/mm2002/062002/weissman.html > accessed 30 September 2014.

${ }^{81}$ Robert Chalmers, 'Evergreen Or Deciduous? Australian Trends in Relation to the 'Evergreening' of Patents' (2006) 30 Melbourne University Law Review 29-61, 29.

${ }^{82}$ Novartis AG v Union of India (UOI) and Ors; Natco Pharma Ltd v UoI \& Ors; M/S Cancer Patients Aid Association v UoI \& Ors. Citations: Civil Appeal No 06-16 of 2013. This decision has been criticised in the USTR report 2013 and remains on the Priority Watch List in 2013. See <http:/www.ustr.gov/sites/default/files/05012013\%202013\% 20Special\%20301\%20Report.pdf> accessed 7 November 2014.

${ }^{83}$ Novartis AG, para 5.
} 
to process'; has 'better processability of the methane sulfonic acid addition salt of a compound of formula I', and has a 'further advantage for processing and storing, ${ }^{84}$ After extensive consideration of the evidence, the Supreme Court of India held that it was unable to accept that Imatinib Mesylate or even Imatinib was not a known substance with known efficacy. ${ }^{85}$ The Court stated that: "It is seen above that Imatinib Mesylate was a known substance from the Zimmermann patent. We thus find no force in the submission that the development of Imatinib Mesylate from Imatinib is outside the Zimmermann patent and constitutes an invention as understood in the law of patent in India'. ${ }^{86}$

This case has been pitched as acting against the incentive for continued research and development in the pharmaceutical fields. It is submitted that the decision does not prevent the patenting of a new drug for the same disease if it is really new and not a minor change in the physical properties of a drug or improved efficacy of a drug due to altering some of the properties.

Developing countries are held to the same standards as developed countries. However, many developed countries did not provide protection for product patents or completely excluded them as patentable subject matter at an earlier stage of their development. ${ }^{87}$ As author Xuan Li remarks, legally such protection prevent all other processes and methods of production of similar chemical products, while economically it creates a monopoly regime. ${ }^{88}$ Regardless of Nigeria's stance, the patent law complies with its obligation as required under article 27 of the TRIPS Agreement.

\footnotetext{
${ }^{84}$ Paragraph 8-9 Novartis AG v Union of India (UOI) and Ors; Natco Pharma Ltd $v$ UoI \& Ors; M/S Cancer Patients Aid Association v UoI \& Ors. Citations: Civil Appeal No 06-16 of 2013.

${ }^{85}$ The decision of the Supreme court was based on section 3 (d) India Patents Act, 1970 (as last amended by Patents (Amendment) Act, 2005) which provides that 'the mere discovery of a new form of a known substance which does not result in the enhancement of the known efficacy of that substance or the mere discovery of any new property or new use for a known substance or of the mere use of a known process, machine or apparatus unless such known process results in a new product or employs at least one new reactant'.

${ }^{86}$ Para 133 Novartis AGv Union of India (UOI) and Ors; Natco Pharma Ltd $v$ UoI \& Or; See also Bristol-Myers Squibb Co v FH Faulding \& Co Ltd 39 (1998) 41 IPR 467 in relation to a petty patent for a more efficient method of administering an anti-cancer drug. At first instance, Heerey $\mathrm{J}$ revoked the patent on various grounds, most controversially that it was a method of treatment, the patenting of which would be generally inconvenient. (Ibid., 479-82) Heerey J quoted Cooke J: 'there remains ... a deep-seated sense that the art of the physician or the surgeon in alleviating human suffering does not belong to the area of economic endeavour or trade 41 (Ibid., 481, citing Wellcome Foundation Ltd $v$ Commissioner of Patents [1983] NZLR 385, 388).

${ }^{87}$ Developed countries that prohibited product patent include France until 1966, Germany until 1967, Switzerland until 1977, Italy until 1978, Spain until 1986 however took effect in 1992.

${ }^{88}$ Xuan Li 'The Impact of Higher Standards in Patent Protection for Pharmaceutical Industries under the TRIPS Agreement A Comparative Study of China and India' UNU World Institute for Development Economics Research (UNU-WIDER) Helsinki, Finland Research Paper No 2008/36, 1-2.
} 


\section{Article 27.2: exclusion from patentability}

The PDA ${ }^{89}$ excludes plant or animal varieties or plant or animal production, essentially biological processes (other than microbiological processes and their products), and inventions the publication or exploitation of which would be contrary to public order or morality ${ }^{90}$ as well as scientific principles and discoveries. ${ }^{91}$ Unlike article 27.2 of the TRIPS Agreement, section 1 (4) (b) of the $\mathrm{PDA}^{92}$ does not require that the exploitation of the invention be of a 'commercial nature'. An invention whose exploitation is contrary to public order or morality is excluded and would be rendered invalid ${ }^{93}$ : all types of exploitation contrary to public order or morality may be excluded from patentability. ${ }^{94}$ The PDA does not specifically exclude the protection of inventions on human health, neither is there a provision that inventions that cause serious prejudice to the environment should be avoided. It must be borne in mind that the Act is a 1970 act which has not been amended since. Therefore issues related to the protection of human life and health, such as gene technology or engineering, ${ }^{95}$ and environmental concerns are more recent and were not envisaged at the time. In particular, the human genome, which is still a developing area in science and biotechnology, was not understood then. Climate change, ${ }^{96}$ global warming, ${ }^{97}$ and the need to avoid serious prejudice to the environment were not topical issues at the time of the adoption of the PDA.

Another issue, related to article 27.2, is the perception that 'some environmentrelated inventions' have been excluded from patent protection. Of particular note are the new chemicals which may contain harmful substances that are not predictable. ${ }^{98}$

\footnotetext{
${ }^{89}$ PDA 1970 P2 LFN 2004, s 1(4) (a) and (b).

${ }^{90}$ According to section 1(4) PDA the exploitation of an invention is not contrary to public order or morality merely because its exploitation is prohibited by law.

${ }^{91}$ PDA 1970 P2 LFN 2004, s 1(5).

${ }^{92}$ PDA 1970 P2 LFN 2004.

${ }^{93}$ Section 24(4)(a) of the South African Patent Law has a similar provision. A similar provision obtains in Ghana, Kenya, Mozambique and Tunisia.

${ }^{94}$ Nuno Pires de Carvalho, The TRIPS Regime of Patent Rights (3rd edn, Kluwer Law International, The Netherlands' 2010) 301.

${ }^{95}$ Modern genetic engineering began in 1973 when Herbert Boyer and Stanley Cohen used enzymes to cut a bacteria plasmid and insert another strand of DNA in the gap. $<\mathrm{http}: / /$ library.thinkquest.org/20830/Manipulating/Experimentation/GenEngineering/history.htm> accessed 18 June 2012.

${ }^{96}$ 'Climate change' means a change of climate which is attributed directly or indirectly to human activity that alters the composition of the global atmosphere and which is in addition to natural climate variability observed over comparable time periods. See Article 1 United Nations Framework Convention on Climate Change (UNFCCC).

${ }^{97}$ 'Global warming is caused by massive increase in greenhouse gasses such a carbon dioxide in the atmosphere resulting from the burning of fossil fuels and deforestation.' See Mark Maslin, Global Warming: A Very Short Introduction (Oxford University Press, Oxford 2009) 1.

${ }^{98}$ Bruce Harper, 'TRIPS Article 27.2: An Argument for Caution', 21 (1997) William \& Mary Environmental Law and Policy Review 381-420, 381; see also Preamble 13 TRIPS Agreement. See also U.S. Gen. Accounting Office, Toxic Substances Control ActLegislative Changes Could Make the Act More Effective 8 (1994). RCED-94-103.
} 
This area has generated a lot of discussion on the relationship with the TRIPS Agreement, the Convention on Biological Diversity (CBD) ${ }^{99}$ and traditional knowledge. ${ }^{100}$ Article 27.2 limits the commercial exploitation of patentable inventions 'in order to protect ... human, animal or plant life ... to avoid serious prejudice to the environment'. On the other hand the, as aptly put by author Kannaiyan ${ }^{101}$ 'CBD is the principal international instruments which explicitly acknowledges the role of traditional knowledge, innovations and practices of indigenous and local communities tangible and visible traditional life styles in biodiversity conservation and its sustainable development.' This exclusion serves to maintain a balance in the use and access of such resources. It also provides a regulated use in a way that 'does not prejudice the people and the environment'.

The aspect of the TRIPS Agreement which is of great concern to developing countries, Nigeria in particular, relates to the dependence on traditional knowledge based on plant remedies by about $80 \%$ of the population. These herbal remedies have been passed down by generations of traditional health practitioners (THPs) ${ }^{102}$ and they play a major role in healthcare provision, ${ }^{103}$ even though they remain largely unregulated and the products used have not undergone laboratory screening.

The exclusion of patentable inventions that relate to human health is conspicuously absent in the PDA. The situation is expected to be amended in consideration of the desperate need for patented drugs for tropical diseases that affect a major part of the country. For example, Nigeria has a 30\% rate of childhood mortality, $11 \%$ rates of maternal mortality and loses about 132 billion nairas annually because of the high susceptibility rate to the scourge of malaria. ${ }^{104}$ Malaria is said to be responsible for over $63 \%$ of all clinical attendances in Nigeria. ${ }^{105}$ According to the 2011 World Report on Malaria, 100\% of the population are at high risk of contracting the disease. ${ }^{106}$

Another issue which the TRIPS Agreement requires before an invention is excluded from patentability is that the exclusion should not be based on the fact that it is prohibited by law in the member state. The PDA complies with this

\footnotetext{
${ }^{99}$ Nigeria ratified the CBD in 1994 . The goals of the CBD are tripartite (1) the conservation of biological diversity, (2) sustainable use of its components, and (3) the fair and equitable sharing of the benefits arising from genetic resources for commercial use. ${ }^{100}$ Pires de Carvalho, (n 108) 199.

${ }^{101}$ S Kannaiyan, 'Biological Diversity and Traditional Knowledge' <http://nbaindia.org/ uploaded/docs/traditionalknowledge_190707.pdf> accessed 7 April 2016.

${ }^{102}$ THPs in Nigeria consist of traditional healers and traditional herbal sellers (known as elewe omo) who have over the years sold all forms of herbal products used for different ailments.

${ }^{103}$ Traditional Medicine as a Tonic for Development <http://www.wipo.int/ipadvantage/en/ details.jsp?id=3229> accessed 2 October 2013.

${ }^{104}$ Emmanuel Adeniyi, 'Global Malaria Cases: Is Nigeria Highest Contributor?' Nigeria Tribune (Sunday, 6 May 2012). See also Monitoring and Evaluation Plan for Malaria Control in Nigeria 2010-2-13 Second Edition September 2011 National Malaria Control Project, Federal Ministry of Health.

${ }^{105}$ National Malaria Control Project, Federal Ministry of Health See also, John C.T. Overview of Malaria Illness in Nigeria. Department of Obstetrics \& Gynaecology, U.P.T.H. Port Harcourt.

${ }^{106}$ World Malaria Report 2011, WHO Library Cataloguing-in-Publication Data, 52.
} 
requirement as the law clearly provides that an invention is not contrary to public order or morality merely because its exploitation is prohibited by law. ${ }^{107}$

\section{Article 27.3 (a): methods of treatment}

The TRIPS Agreement allows members of the WTO to exclude from patentability diagnostic, therapeutic and surgical methods for the treatment of humans or animals. ${ }^{108}$ This is an important exception which is not specifically found in the PDA. The silence of the PDA can mean that diagnostic, therapeutic and surgical methods for the treatment of humans or animals may be patentable. However, since such methods are not industrially applicable they may not be patentable even in the absence of specific exclusion. ${ }^{109}$ Generally, speaking, most coun$\operatorname{tries}^{110}$ do not patent methods of treatment ${ }^{111}$; however, the United States (US) stands out as an exception to the rule. ${ }^{112}$ It is believed in the US that 'everything under the sun made by man is patentable'. ${ }^{113}$ Some countries, like India, have extended the provision further so that 'any process for the medicinal, surgical, curative, prophylactic diagnostic, therapeutic or other treatment of human beings or any process for a similar treatment of animals to render them free of disease or to increase their economic value or that of their products ${ }^{\prime 14}$ are excluded

${ }^{107}$ PDA 1970 P2 LFN 2004, s 1 (4) (b).

${ }^{108}$ TRIPS Agreement, art 27.3 (a).

${ }^{109}$ UNCTAD. Resource Book on TRIPS p 384.

${ }^{110}$ Albania, Algeria, Andorra, Argentina, Austria, Bahrain, Barbados, Belgium, Belize, Bolivia, Bosnia \& Herzegovina, Brazil, Canada, Chile, China, Colombia, Costa Rica, Croatia, Dominica, Ecuador, Egypt, El Salvador, Estonia, Ethiopia, Finland, France, Georgia, Germany, Ghana, Greece, Guatemala, Hungary, Iceland, India, Indonesia, Ireland, Israel, Italy, Japan, Jordan, Kenya, Latvia, Lebanon, Liechtenstein, Lithuania, Luxembourg, Malaysia, Malta, Mauritius, Mexico, Mongolia, Morocco, Mozambique, Netherlands, Nicaragua, Norway, Pakistan, Panama, Papua New Guinea, Peru, Philippines, Poland, Portugal, Qatar, Romania, Santa Lucia, Saudi Arabia, Serbia, Singapore, Slovak Republic, Slovenia, South Africa, Spain, Sri Lanka, Sweden, Switzerland, Tanzania, Thailand, Former Yugoslav Republic of Macedonia, Trinidad \& Tobago, Tunisia, Turkey, Uganda, United Kingdom, Uruguay.

${ }^{111}$ According to Piper there are approximately 80 countries around in the world that exclude methods of medical treatment from being granted patent protection. These include all European countries (Article 53(c) \& Article 52 (4)European Patent Convention 1973), some countries in Asia, Africa ( In South Africa section 25 (11) of the current Patent Act 57 of 1978 last amended by (Patents Amendment Act, No 58 of 2002 ) provides that: "An invention of a method of treatment of the human or animal body by surgery or therapy or of diagnosis practised on the human or animal body shall be deemed not to be capable of being used or applied in trade or industry or agriculture.), North America, South America, and Central America. See Tina, Commentary in response to 'Are Patents for Methods of Medical Treatment contrary to the Ordre Public and Morality or “'Generally Inconvenient"?', (2004) 30 Journal of Medical Ethics 470, 476; section 4A(1) of the UK Patents Act 1977 (as amended).

${ }^{112}$ Eddy Ventose, Medical Patent Law The Challenges of Medical Treatment (Edward Elgar 2011) 9.

${ }^{113}$ Diamond v Chakrabarty - 447 U.S. 303 (1980).

${ }^{114}$ India Patents Act, 1970, s 3 (1) (as last amended by Patents (Amendment) Act, 2005). 
from patent protection. The European Patent Act, in two separate articles, in different ways state that methods of treatments are not inventions ${ }^{115}$ and are not patentable. ${ }^{116}$ The reason for the emphasis on this exception was given by the Technical Board of Appeal (TBA) in THOMPSON/Cornea, ${ }^{117}$ where it states:

The intention underlying [Article 52(4)] is to ensure that nobody who wants to use the methods specified in this Article as part of the medical treatment of humans or animals should be prevented from this by patents. Such medical treatments need not necessarily be carried out by physicians ... However, where, in view of the health risks connected with such a treatment, a claimed method of treatment has to be performed by a physician or under his supervision, it will normally fall within the exclusion ...

Therefore, methods of treatment have been distinguished by the mode of treatment to enable protection. For instance, appetite suppressants ${ }^{118}$ have been held to be patentable, however, ccontraceptive methods ${ }^{119}$ an apparatus for skin resurfacing $^{120}$ and hair removal methods ${ }^{121}$ are not patentable.

Consequently, in the absence of this provision in the PDA, it can develop in either direction. However, some of the methods of treatment may be disallowed as being contrary to public order or morality which is an exception under the PDA, ${ }^{122}$ especially if it is held that 'ethical grounds' mean 'public policy grounds'.

Article 27.3 (b): micro-organisms non-biological and microbiological processes

Article 27.3 (b) contains issues which are still controversial. ${ }^{124}$ This article essentially provides that members may exclude plants and animals, but not micro-organisms,

\footnotetext{
${ }^{115}$ European Patent Convention 1973, art 52 (4).

${ }^{116}$ European Patent Convention 1973, art 53 (c).

${ }^{117} \mathrm{~T}$ 24/91 THOMPSON/Cornea OJEPO 1995, 512.

${ }^{118}$ T144/83 - DU PONT [1986] OJEPO 301-05 The Board allowed the protection of an appetite suppressant the summary of the Board decision is stated as follows: 'The fact that a chemical product has both a cosmetic and therapeutic effect when used to treat the human or animal body does not render the cosmetic treatment patentable (as in the present case where it may be used to cause loss of weight or to cure obesity)'.

${ }^{119}$ T 0820/92 $1994<\mathrm{http}$ //www.epo.org/law-practice/case-law-appeals/recent/t920820ep1. html $>$ accessed 1 October 2015.

${ }^{120} \mathrm{~T} 1172 / 03$ of 4.5 .2005 Held 'The patentability of a surgical method claimed as a cosmetic method must be excluded, if the cosmetic use of the method is only expressed in the claim as a mere intention of the person using the method'.

${ }^{121} \mathrm{~T}$ 383/03 (2005) OJEOPO 159-General Hospital Corp/Hair removal method. Method of treatment by surgery not excluded from patentability 'if a method involving a physical intervention on the human or animal body (treatment by surgery) is clearly neither suitable nor potentially suitable for maintaining or restoring the health, the physical integrity, or the physical well-being of the person or animal, then the method does not fall under the exclusion from patentability provided for in Article 52(4) EPC'.

${ }^{122}$ PDA 1970 P2 LFN 2004, s 1 (4).

${ }^{123}$ J Per Finkelstein, in Bristol Myers Squibb Co v F H Faulding \& Co Ltd (2000) 46 IPR 553586.

${ }^{124}$ Gervais Daniel, The TRIPS Agreement Drafting History and Analysis (4th edn, Sweet and Maxwell Croydon 2012) para 2, 371p 454. See also UNCTAD. Resource Book on TRIPS, 388.
} 
and essentially biological processes for the production of plants or animals may not be protected, but non-biological and microbiological processes may be. However, any country excluding plant varieties from patent protection must provide an effective sui generis system of protection. In addition, the whole provision is subject to review four years after entry into force of the Agreement. ${ }^{125}$ The PDA excludes plant or animal varieties or essentially biological processes for the production of plants or animals, but does not specifically exclude micro-organisms and non-biological processes from patentability. ${ }^{126}$ Protecting micro-organisms, non-biological and microbiological processes of plants and animals has been a source of serious debate internationally. The provision aligns with the Nigerian position on the issue of patenting of life forms. ${ }^{127}$

There was an attempt in 1999 to review article 27.3 (b) which, in turn, raised several issues at the TRIPS Council, discussions amongst which was the application of this provision. Issues that were raised included whether patentability extends to plants and animals and whether the provisions need to be modified, and how moral and ethical issues are dealt with, for example, to what extent invented life forms should be eligible for protection under the provision. ${ }^{128}$ For these reasons several developing countries have called for the review of this section. In 2003 the African Group ${ }^{129}$ maintained its reservations about patenting any life forms: they declared such patenting to be unethical and that the TRIPS Agreement should prohibit it by modifying the requirement to exclude form protection all patents on micro-organisms and on non-biological and microbiological processes for the production of plants or animals. ${ }^{130}$

The African group, and certain other members of the WTO, consider patents on life forms to be contrary to the fabric of their society and culture and to be immoral. Such protection, they feel is contrary to the exception in article 27.2 regarding ordre public and morality, which otherwise would be meaningless. ${ }^{131}$ Bolivia expressed serious concerns, contending that 'the patent system has

${ }^{125}$ This is the only section which is subject to review every four years, thus the first review should have been 1999 and subsequently 2003, 2007, 2011. This review was inserted as a result of biotechnology which was and is still a developing area.

${ }^{126}$ PDA 1970 P2 LFN 2004, s 1 (4).

${ }^{127} \mathrm{IP} / \mathrm{C} / \mathrm{W} / 404$ - Taking forward the review of article 27.3(b) of the TRIPS Agreement. Joint Communication from the African Group. Council for Trade-Related Aspects of Intellectual Property Rights. 26 June 2003.

${ }^{128}$ TRIPS: Reviews, Article $27.3(\mathrm{~b})$ and related issues <http://www.wto.org/english/ tratop_e/trips_e/art_3b_background_e.htm> accessed 1 October 2013.

${ }^{129}$ WTO Members $(4 \overline{2})$ : Angola, Benin, Botswana, Burkina Faso, Burundi, Cameroon, Cape Verde, Central African Rep., Chad, Congo, Congo (Democratic Rep.), Côte d'Ivoire, Djibouti, Egypt, Gabon, Gambia, Ghana, Guinea, Guinea Bissau, Kenya, Lesotho, Madagascar, Malawi, Mali, Mauritania, Mauritius, Morocco, Mozambique, Namibia, Niger, Nigeria, Rwanda, Senegal, Sierra Leone, South Africa, Swaziland, Tanzania, Togo, Tunisia, Uganda, Zambia, Zimbabwe.

${ }^{130} \mathrm{IP} / \mathrm{C} / \mathrm{W} / 404-$ Joint Communication from the African Group. Council for Trade-Related Aspects of Intellectual Property Rights. 26 June 2003; Boniface Guwa Chidyausiku, 'Article 27.3 (b) of the TRIPS Agreement the Review Process and Development at National and Regional Level', in Christophe Bellmann and Ricardo Melendez-Ortiz (eds), Trading in Knowledge: Development Perspectives on TRIPS, Trade and Sustainability (Earthscan 2003) 101-08, 104.

${ }^{131} \mathrm{IP} / \mathrm{C} / \mathrm{W} / 404$ - African Group. 
become an instrument of privatisation and commoditisation of life itself on a worrying scale and magnitude'. ${ }^{132}$ It stressed: 'for the indigenous peoples of Bolivia and of many other peoples of the world, life is something sacred that under no circumstances should be subject to private appropriation or considered as a commodity'. 133

As remarked by Dutfield, ${ }^{134}$ this aspect of the TRIPS Agreement is undoubtedly extremely important for developing countries, including Nigeria. Reflecting on what article 27.3(b) means to developing countries, he suggests ways to advance the debate and explicitly states that although the TRIPS Agreement requires WTO members to protect biotechnological inventions, article 27.3(b) nevertheless provides the possibility of members regulating the degree of protection that would be offered for technological invention ${ }^{135}$ by providing an option to protect plant varieties through patents or by an effective sui generis system.

The dilemma most developing countries face is explained by Dutfield. He gives several reasons why biotechnology is not out-right bad and patentability should not be discarded without looking at the benefits that can be attained from such protection. He explains that there seems to be a disconnection in the interpretation of biotechnologies and that the bone of contention is the "new biotechnologies'. 136 'Longer-established biotechnologies' are acceptable, and the main issue is that industrial countries (ICs) and developing countries (DCs) 'are applying the word "biotechnology" differently'. 137 The main difference between the two types of biotechnology is not clear cut as the distinction can only be derived from the fact that the 'longer established biotechnologies' have generally become acceptable in the society as they are not looked at from the lenses of biotechnologies any longer ${ }^{138}$ while new bio-technologies are often misunderstood and ill-defined only in relation to genetically modified organisms (GMOs) ${ }^{139}$ whereas it include medical and health care breakthrough products, environmentally friendly products geared towards the use of less and cleaner energy, and more efficient industrial manufacturing processes. ${ }^{140}$ Consequentlty, Dutfield opines

\footnotetext{
${ }^{132}$ TRIPS Council discusses Art 3 (b) review, 'Para 6' system Published in SUNS \#6945 dated 16 June 2010 TWN Info Service on Health Issues Third World Network 6 July $2010<$ http://www.twnside.org.sg/title2/health.info/2010/health20100701.htm> accessed 2 October 2013.

${ }^{133}$ TRIPS Council discusses Art 3 (b) review, 'Para 6' system.

${ }^{134}$ Graham Dutfield, 'Biotechnology and Patents: What Can Developing Countries Do About Article 27.3(b)?' BRIDGES between Trade and Sustainable Development ICTSD ANALYSIS Post-Doha Ministerial Issue November/December (2001) 5(9), $17<\mathrm{http} / / /$ ictsd.org/downloads/bridges/bridges5-9.pdf> accessed 2 October 2013.

${ }^{135}$ Tshimanga Kongolo, Unsettled International Intellectual Property Issues (Kluwer Law International 2008) 89; Boniface guwa Chidyausiku Article 27.3 (b) of the TRIPS Agreement the review process and development at national and regional level in Christophe Bellmann, Ricardo Melendez-Ortiz (eds), Trading in Knowledge: Development Perspectives on TRIPS, Trade and Sustainability (Earthscan 2003) 101-08, 108.

${ }^{136}$ Such as recombinant DNA, monoclonal antibodies and genomics.

${ }^{137}$ Dutfield, (n 147) 17.

${ }^{138}$ Examples of long established biotechnologies are beer brewing and bread making.

${ }^{139}$ Giovanni Tagliabue, 'The Precautionary principle: its misunderstandings and misuses in relation to "GMOs" 33(4) New Biotechnologies 437-39.

${ }^{140}$ What is Biotechnology? <https://www.bio.org/articles/what-biotechnology $>$ accessed 6 April 2016.
} 
that developing countries are expected to take a TRIPS de minimis approach: to define the terms restrictively where it is advantageous to do so. He advises that it is in the interest of developed countries 'to heed the concerns of developing countries and respond sympathetically'. He states that it is unreasonable to pressure developing countries into implementation and that developed countries should 'refrain from imposing their own interpretations of article 27.3 (b) based on their own legislation, jurisprudence and economic interests'. ${ }^{141}$

Although Nigeria has rudimentary biotechnological means at the moment there is a movement toward better access to biotechnology that suits the current level of development. National programmes that will empower Nigerians and impart 'the capacity to decide on how to use these technologies in consideration of national regulatory system, ${ }^{142}$ are being introduced systematically.

On the continental level in 2001 the African Union drafted an African Model Law on Safety in Biotechnology ${ }^{143}$ which was confirmed by the 37 th Assembly of Heads of State and Government, including Nigeria. ${ }^{144}$ The African Model Law on Biosafety ${ }^{145}$ was developed to assist African countries in crafting their national laws on biosafety by giving the necessary technical options in dealing with the regulation of issues on biosafety that are readily adaptable to suit local needs and to meet national objectives. The Cartagena Protocol on Biosafety ${ }^{146}$ informed the enactment of the African Model Law on Biosafety to ensure more rigorous standards and additional bio-safety measures in Africa in relation to biotechnology. ${ }^{147}$

Apart from the African Union Model Law there are other initiatives by Regional Economic Communities (RECs). In relation to Nigeria, the Economic Community of West African States (ECOWAS) in 2005 held a Ministerial Conference of ECOWAS States on Biotechnology in Bamako, Mali. ${ }^{148}$

\footnotetext{
${ }^{141}$ Dutfield, (n 147) 18.

${ }^{142}$ Dele Ogbodo, 'Gates Foundation to Build Standard Biotech Lab in Nigeria' (Tuesday 9 Jul 2013) <http://www.thisdaylive.com/articles/gates-foundation-to-build-standard-bio tech-lab-in-nigeria/152816/> accessed 3 October 2015.

${ }^{143}$ Revised August, 2007 and now called African Model Law on Biosafety.

${ }^{144}$ African Model Law on Biosafety Overview <http://www.africa-union.org/root/AU/ AUC/Departments/HRST/biosafety/AU_Biosafety_2b.htm> accessed 4 October 2015.

${ }^{145}$ An African Position on GMOS in Agriculture African Union Commission Directorate of Rural Economy and Agriculture <http://hrst.au.int/en/sites/default/files/2007-Presenta tion-AfricanGMOPosition.pdf $>$ accessed 2 October 2015.

${ }^{146}$ Cartagena Protocol on Biosafety to the Convention on Biological Diversity. Montreal, 29 January $2000<$ http://www.cbd.int/doc/legal/cartagena-protocol-en.pdf $>$ accessed 2 August 2015.

${ }^{147}$ African Ministerial Conference on Science and Technology (AMCOST III) Third Ordinary Session 12-16 November 2007 Mombasa, Republic Of Kenya Au/Exp/St/17 (Iii) African Model Law on Safety in Biotechnology <http:/www.africa-union.org/root/AU/ Conferences/2007/November/HRST/AMCOST/docs/pdf/AU-EXP-ST-17_III_-ENG-Report $\% 20$ of\%20Experts\%20on\%20Model\%20Law.pdf> accessed 4 August $2 \overline{015}$.

${ }^{148}$ ECOWAS Ministerial Conference on Biotechnology: Strategies and actions for sustainable agricultural production, safe for humans and environment Bamako, 21-24 June 2005.
} 
The Conference was a summation of meetings and workshops held in Ouagadougou $^{149}$ and Abuja ${ }^{150}$ with the aim of proposing recommendations for a better understanding of biotechnology and its potential applications. The conference recommended some guidelines which ECOWAS countries should adopt to ensure the safe utilisation of biotechnology and suggested the following: (i) the development and use of biotechnologies (ii) a regional approach for biosafety (iii) an information and communication strategy and policy in biotechnology, and (iv) the institutionalisation of a ministerial conference on biotechnology. ${ }^{151}$ In 2007, there was a follow-up meeting in Ghana of the ministers of agriculture, environment, science and technology to discuss the issues surrounding biotechnology in agriculture. ${ }^{152}$ The aim of the Conference was to come up with an action plan on biotechnology and bio-safety and 'to stimulate competitiveness, while maintaining the natural resource base and creating an enabling environment. ${ }^{, 153}$ It also agreed to reduce food insecurity in the region by using appropriate technology, including biotechnology. Nevertheless, it was proposed to set up safety measures at national and regional levels and to set aside independent fund to assess the socio-economic impact of using GMOS. ${ }^{154}$

Obviously, West Africa, including Nigeria, is taking steps toward the use of biotechnology. However, they are still skeptical about the implementation of article 27.3 (b). Patentable or non-patentable subject matter will be a topic of discussion for a long time to come as the developing and least developed countries are not at a level of development already attained by countries such as the US, Canada, Europe and Japan. Regrettably, Nigeria has not reached the level of technological development required to use a lot of the inventions that are a source of concern for ICs. This is evident in the fact that there has been no real

\footnotetext{
${ }^{149}$ Conference on 'Controlling sciences and technologies to increase agricultural productivity in Africa: a West African perspective' was held in June 2004 in Ouagadougou, Burkina Faso.

${ }^{150}$ Conference on 'The Utilization of Science and Technology to Increase Agricultural Productivity in Africa' was held in June 2004 in Ouagadougou, Burkina Faso. Conference of the Ministers in Charge of Science and Technology was held in Abuja in November 2004 with the theme of 'Agriculture and Biotechnology'.

${ }^{151}$ Recommendation Establishing a Technical Commission on Biotechnologies Applied to Agriculture. Briefing Document ECOWAS Ministerial Conference on Biotechnology: Strategies and actions for sustainable agricultural production, safe for humans and environment Bamako, 21-24 June $2005<\mathrm{http} / / /$ www.hubrural.org/IMG/pdf/cedeao_ba mako_group_report3_recommendations_eng.pdf $>$ accessed 7 August 2015.

${ }^{152}$ ECOWAS Ministerial Conference on Biotechnology: 'Adoption of 2006-2010 Action Plan for Meeting of the Challenges of Biotechnology and Bio safety.' Accra Ghana 2830 March 2007.

${ }^{153}$ Action plan for the development of biotechnology and bio-safety in the ECOWAS sub-region <http://www.coraf.org/documents/Action $\% 20$ Plan $\% 20$ for $\% 20$ Biotech $\% 20$ of $\%$ 20ECOWAS.pdf $>$ accessed 7 October 2013.

${ }^{154}$ West Africa to boost food crops with biotechnology <http://www.scidev.net/subsaharan-africa/biotechnology/news/west-africa-to-boost-food-crops-with-biotechnology-ssa. html $>$ accessed 7 October 2013.
} 
push by ICs for Nigeria to comply with its international obligation. The first sentence of article 27.3 (b) is an optional provision which countries may adopt if they deem fit, accordingly, Nigeria's position is not at variance with what is expected under the TRIPS Agreement.

\section{Article 27.3 (b): plant and animals}

The TRIPS Agreement, in addition, requires members to protect plant varieties either by patents or an effective sui generis system or by any combination. ${ }^{155}$ The TRIPS Agreement excludes plant life form protection, however, it provides for the protection of plant varieties. What are plants and what are plant varieties? A plant has been defined as 'first of all, a living thing and shares the characteristics which are recognised as life with other living things.' ${ }^{156}$ Plant variety is defined in the UPOV Convention as ${ }^{157}$ 'a plant grouping within a single botanical taxon of the lowest known rank, which grouping, irrespective of whether the conditions for the grant of a breeder's right are fully met, can be (1) defined by the expression of the characteristics resulting from a given genotype or combination of genotypes (2) distinguished from any other plant grouping by the expression of at least one of the said characteristics and (3) considered as a unit with regard to its suitability for being propagated unchanged'.

A variety must be recognisable by its characteristics, be recognisably different from any other variety and remain unchanged through the process of propagation. ${ }^{158}$ It is the contention of developing countries and for this reason that they ask whether plant varieties should be included in genetically-engineered plant varieties and, therefore, get patent protection as such. ${ }^{159}$ The interpretation leads to the discussion on the patenting of life forms, which is why most developing countries are apprehensive, Nigeria inclusive.

The Doha Declaration ${ }^{160}$ broadened the discussion. ${ }^{161}$ It declared that the TRIPS Agreement Council should look at the relationship between the TRIPS

${ }^{155}$ TRIPS Agreement, art 27.3 (b).

${ }^{156}$ James C Forbes and R Drennan Watson, Plants in Agriculture (Cambridge University Press, Cambridge 2006) 2.

${ }^{157}$ UPOV Convention, art 1 (vi).

${ }^{158}$ The UPOV System of Plant Variety Protection <http://www.upov.int/about/en/upov_sys tem.html\#what is a pv> accessed 3 September 2015.

${ }^{159}$ Dutfield. (n $\left.\overline{1} 4 \overline{7}\right) \overline{18}$.

${ }^{160}$ The 4th WTO Ministerial meeting at Doha, Qatar adopted, on the 14 November 2001, a Declaration on the TRIPS Agreement and Public Health. The Declaration was conceived mainly as a result of apprehensions about the likely impact of the TRIPS Agreement on access to medicines. The Declaration stresses that the TRIPS Agreement does not and should not preclude the use of the flexibilities by WTO members to protect public health. The Declaration took special notice of the gravity of the problems afflicting developing and least developed countries with regard to diseases like HIV/AIDS, tuberculosis, malaria and other epidemics. See also WT/MIN (01)/DEC/2 (emphasis added).

${ }^{161}$ The Doha Declaration 2001, para 19. 
Agreement and the UN CBD, the protection of traditional knowledge and folklore. The declaration specifically provides that the TRIPS Agreement Council's work on these topics should be guided by the TRIPS Agreement's objectives ${ }^{162}$ and principles ${ }^{163}$ and must take developmental issues fully into account. ${ }^{164}$ This is essentially so because there have been reports that intellectual property rights on plant varieties erode biological diversity, especially in agriculture.

The treaty for the protection of plant varieties internationally, is the International Convention for the Protection of New Varieties of Plants (UPOV). ${ }^{165}$ Nigeria is not a party to the UPOV. UPOV has been said to be an effective system of plant protection: it is not obligatory to choose this system of protection. ${ }^{166}$ Nigeria has a National Crop Varieties and Livestock Breeds Registration and Release Committee ${ }^{167}$ and a National Agricultural Seed Service, ${ }^{168}$ which were promulgated to regulate the system of naming, release and registration of crop varieties and livestock breeds and, consequently, to keep a check on the seed industries. ${ }^{169}$ The objective has not been realised as a result of structural and functional defects in the law. ${ }^{170}$

Nigeria signed the CBD at the United Nations Earth Summit in June 1992 and ratified it in August 1994. Nigeria is a party to the Cartagena Protocol and its Supplementary Protocol, ${ }^{171}$ but is not a party to the Nagoya Protocol. ${ }^{172}$ There is no specific domestic legislation on biological diversity: however, there

\footnotetext{
${ }^{162}$ TRIPS Agreement, art 7.

${ }^{163}$ TRIPS Agreement, art 8 .

${ }^{164}$ WTO DOHA MINISTERIAL DECLARATION 2001 Adopted on 14 November 2001 WT/MIN(01)/DEC/1 Paragragh 19 'We instruct the Council for TRIPS, in pursuing its work programme including under the review of Article 27.3(b), ... In undertaking this work, the TRIPS Council shall be guided by the objectives and principles set out in Articles 7 and 8 of the TRIPS Agreement and shall take fully into account the development dimension'.

${ }^{165}$ Act of 1991 International Convention for the Protection of New Varieties of Plants of December 2, 196, as Revised at Geneva on 10 November 1972, on 23 October 1978, and on 19 March 1991.

${ }^{166}$ Gervais, (n 137) 456.

${ }^{167}$ National Crop Varieties and Livestock Breeds (Registration, etc.) Act Cap N27 Decree 33 of 1987.

${ }_{168}^{16}$ National Agricultural Seeds Act 1992 Cap N5 LFN 2004.

${ }^{169}$ Ibigbami and Orji, 'A Review of the Nigerian System of Intellectual Property A Case Study Under NABDA/CAS-IP NPI Collaboration Project Intellectual Property Desk National Biotechnology Development Agency' <http://www.iccwbo.org/uploadedFiles/ BASCAP/Pages/A\%20Review\%20of $\% 20$ the $\% 20$ Nigerian $\% 20$ System $\% 20$ of $\% 20$ Intellec tual\%20Property.pdf $>$ accessed 2 August 2015.

${ }^{170}$ Review of the National Agricultural Seeds Act and Proposed Amendments. A report of Seed law review Committee. At <http://pdf.usaid.gov/pdf_docs/PNADC079.pdf $>$ accessed 2 August 2015.

${ }^{171}$ Nigeria signed the protocol in May 2000 and ratified it in October 2003.

${ }^{172}$ Nagoya - Kuala Lumpur Supplementary Protocol on Liability and Redress.
} 
are other legislations on environmental protection of significance which may be taken into account. ${ }^{173}$

As stated earlier, ${ }^{174}$ the IPCOM Bill included an Act on Plant Varieties, Animal Breeders and Farmers Rights ${ }^{175}$ largely this reflects the intent of the African Model Law on Safety in Biotechnology. The Bill provides for the registration of plant varieties and animal breeds ${ }^{176}$ and for registering the description of the plant variety or animal breed. As well, the denomination and name of the variety or breed as may be prescribed if it conforms to such criteria of distinctiveness, uniformity and stability as shall be specified by regulations of the Bill. ${ }^{177}$ The registration of plant varieties and animal breeds unlike patent applications which are based on mere formalities demanded that with the application samples of the variety or breed will be sent to the National Crop Varieties and Livestock Breeds Registration and Release Committee for the purpose of conducting tests to evaluate whether such a variety, along with parental material, conforms to the standards specified by regulations. ${ }^{178}$ The Bill, as stated above, has not been passed into law.

From the above discussion it can be seen that Nigeria, along with other African countries, is moving towards compliance with the TRIPS Agreement. However, it is safe to say Nigeria has not complied with its obligation for the protection of plant varieties, either by patents or by an effective sui generis system or by any combination thereof under article 27.3(b) of the TRIPS Agreement.

\section{Modification required in the Patent and Designs Act}

The Patent and Designs Act mostly complies with the TRIPS Agreement. However certain aspects of the PDA need to be amended to fully comply, as well as to take the necessary flexibilities into account. The PDA also requires better structuring in plain and simple language.

\section{Patentable inventions}

Section 1 of the PDA is the core provision of the patent legislation. For a better understanding of the PDA, patentable inventions need to be defined more comprehensively. Patents and inventions are not defined in the PDA: this is

\footnotetext{
${ }^{173}$ These include Harmful Waste (Special Criminal provisions etc.); Decree, 1988, the Environmental Impact Assessment decree 1992,Public Health Act, 1917 Antiquities Act, 1915, Live Fish (Control of Importation) Act, 1965, Navigable Waters Declaration Decree, 1978, Natural Resources Conservation Council Decree, 1989 River Basins Development Authorities Decree, 1987, Sea Fisheries (licensing) Regulations, 1992, Quarries Decree, 1969, National Parks Decree, 1991NIGERIA, National Biodiversity Strategy and Action Plan at <http://www.cbd.int/doc/world/ng/ng-nbsap-01-en.pdf $>$ accessed 19 June 2015.

${ }^{174}$ Paragraph 6.2.4 above 'Recent development in Patent laws'.

${ }^{175}$ The Plant Varieties, Animal Breeders and Farmers Rights in Part D of the IPCOM Bill is up till now still a Bill.

${ }^{176}$ IPCOM Bill 2006, s 172-175.

${ }^{177}$ IPCOM Bill 2006, s 175 (2).

${ }^{178}$ IPCOM Bill 2006, s 180 (2).
} 
important; as it gives meaning to what is patentable. The section consists of the three requirements under the TRIPS Agreement as well as improvements: an allinclusive meaning of each requirement is needed. In addition, patentable subject matter is completely absent from the PDA which leaves it open to varying interpretation. $^{179}$

\section{Conclusion}

The discussion on the patent system in Nigeria reveals that the Patent and Design Act does not have numerous shortcomings with regard to the protection of right holders. However, the flexibilities afforded by the TRIPS Agreement are absent.

With regard to the requirements needed for protection there is compliance with the TRIPS Agreement, although criticism may be levied against the implicit nature of the way the provision ${ }^{180}$ is drafted which leaves a possibility for misinterpretation. The absence of a well-defined interpretation section for the requirements makes it vague and subject to misuse. It is submitted that the provision is outdated and not in line with developments in other jurisdictions.

Therefore, it is proposed that section 1, which provides for the requirements of patentable inventions, should be explicit in its definition of new results from inventive activity and which are capable of industrial application. Also, a provision on patentable subject matter needs to be included in the Act to enable easy recognition of what is patentable, although the TRIPS Agreement does not leave many options because of the requirement that patents shall be available for any inventions, whether products or processes, in all fields of technology. Also, provisions on the ability to obtain patents on improvements should be explored to the fullest.

Furthermore, the fact that the patent system does not take advantage of all the possible flexibilities that are available constitutes a strangle-hold on users as well as producers. Consequently, there is a need for reform, taking into consideration the socio-economic and public health issues facing Nigeria. Accordingly harnessing all the possible flexibilities will develop the present stagnant technological expertise and industry which are required for economic and social advancement.

Other practical concerns relate to the employee/employer relationship which may limit incentives to invent and, as a result, affect innovation and the patenting system generally. A weak institutional framework for the transfer of technology is another barrier to the effective use of the patent system as the use of technology, even in the public domain, constitutes a challenge.

Patent laws should not be seen as a clog in the wheel of progress; rather they should be seen as a document which inspires innovation for all and can be used as an instrument for managing the political economy of the country ${ }^{181}$ to foster development.

\footnotetext{
${ }^{179}$ PDA 1970 P2 LFN 2004, s 1.

${ }^{180}$ Ibid.

${ }^{181}$ Report on the Revision of Patent Law Justice N Rajagopala Ayyangar Committee September 1959.
} 


\section{Disclosure statement}

No potential conflict of interest was reported by the author.

\section{Notes on contributor}

Temitope O. Oloko is a lecturer at Lagos State University, she is currently a LLD candidate at the University of Pretoria, her area of research is intellectual property, specifically the impact of the TRIPS Agreement on Nigeria. She has been a lecturer for 11 years with a specialized masters in intellectual property commerce and technology from Franklin Pierce Law center in New Hampshire. She has written several publications in this area particularly as it relates to Nigeria. 